\title{
Origin of carbonate cements in deep marine siliciclastic turbidites revealed by SIMS and LA-ICP-MS micro- analyses
}

\author{
FARES AZZAM ${ }^{1}$, THOMAS BLAISE ${ }^{1}$, BENJAMIN \\ BRIGAUD $^{2}$, JOCELYN BARBARAND ${ }^{2}$, PATRICIA \\ PATRIER $^{3}$ AND ERIC PORTIER $^{4}$
}

${ }^{1}$ Paris Saclay University

${ }^{2}$ Université Paris-Saclay, CNRS, GEOPS

${ }^{3}$ Institut de Chimie des Milieux et Matériaux de Poitiers

${ }^{4} \mathrm{CV}$ Associes Engineering

Presenting Author: Fares.199@live.com

Carbonates are common authigenic minerals in siliciclastic reservoirs, forming barriers to fluid circulation. Understanding their origin and distribution is therefore important to optimize well locations and production from any underground reservoir. Here, we discuss the origin of siderite coatings and calcitecemented layers in the turbiditic sandstones of the Albian Agat Formation in the northern North Sea.

Siderite occurs as a minor diagenetic mineral forming coatings around detrital grains. Electron probe microanalysis reveals chemical zonation within the siderite crystals. The Fe content decreases from the core to the edge of the crystals, while $\mathrm{Ca}$ and $\mathrm{Mg}$ increase. SIMS microanalysis of siderite also reveals variations in $\delta^{18} \mathrm{O}$ and $\delta^{13} \mathrm{C}$ showing depletion in the inner zone $\left(\delta^{18} \mathrm{O} \approx-5.71 \%{ }_{\mathrm{PDB}}\right.$ and $\left.\delta^{13} \mathrm{C} \approx-28.95 \%{ }_{\mathrm{PDB}}\right)$ and enrichment in the outer zone $\left(\delta^{18} \mathrm{O} \approx+0.61 \%{ }_{\mathrm{PDB}}\right.$ and $\left.\delta^{13} \mathrm{C} \approx-10.85 \%{ }_{\mathrm{PDB}}\right)$. Such zonation is consistent with siderite growth from microbial activity at shallow depth. Siderite cores precipitated in the Fereduction zone, while the rims likely precipitated in the methanogenesis zone, where $\mathrm{Fe}^{2+}$ content decreases.

Two generations of calcite cement were identified based on petrographic observations. Calcite 1 shows a sparry texture with crystal sizes ranging from $20 \mu \mathrm{m}$ up to $180 \mu \mathrm{m}$. Calcite 2 appears as a poikilotopic cement with crystals reaching $350 \mu \mathrm{m}$. Fluid inclusion microthermometry in calcite 2 and $\delta^{18} \mathrm{O}$ values $(-10.9$ to $\left.-11.5 \%{ }_{\mathrm{PDB}}\right)$ reveals high crystallization temperature between 85 and $115^{\circ} \mathrm{C}$. Conversely, the $\delta^{18} \mathrm{O}$ values of calcite 1 (-4 to -5.9 $\%_{\mathrm{PDB}}$ ) suggests lower crystallization temperature during early diagenesis $\left(20-45{ }^{\circ} \mathrm{C}\right)$. The low $\delta^{13} \mathrm{C}$ values in both calcites indicates an organic source of carbon. Elemental analysis by LAICP-MS shows similar REE distribution in both calcites, comparable to the bulk hosting rocks. This suggests that calcite precipitation was derived from local pore fluids and that calcite 2 precipitated from the dissolution of calcite 1 .

This study reveals for the first-time an isotopic zonation in siderite crystals showing the importance of in-situ SIMS microanalysis at mineral-scale. Also, it shows that combining SIMS and LA-ICP-MS microanalyses enables to distinguish between different calcite cement and to trace the evolution in the chemistry of pore fluids. 